\title{
The impact of diabetes mellitus on the survival of patients with acromegaly
}

\author{
Wpływ cukrzycy na przeżycie pacjentów z akromegalią
}

\author{
Chiou Wen-Ko ${ }^{1}$, Chen Szu-Ta ${ }^{2}$, Liu Feng-Hsuan ${ }^{2}$, Chang Chen-Nen ${ }^{3}$, Wang Ming-Hsu' ${ }^{1}$, Lin Jen-Der \\ ${ }^{1}$ Department of Industrial Design, Healthy Aging Research Centre, Chang Gung University, Taiwan \\ ${ }^{2}$ Division of Endocrinology and Metabolism, Department of Internal Medicine, Chang Gung Memorial Hospital, Chang Gung \\ University, College of Medicine, Taiwan \\ ${ }^{3}$ Department of Neurosurgery, Chang Gung Memorial Hospital and Chang Gung University, College of Medicine, Taiwan
}

\begin{abstract}
Introduction: An increased risk of mortality in patients with uncontrolled acromegaly has been reported in several studies. We aimed to assess the impact of co-morbidities on the survival of patients with acromegaly after long-term treatment and follow-up.

Materials and methods: A retrospective analysis was performed for 285 patients with active acromegaly, who were admitted to the Chang Gung Memorial Hospital, Taiwan between 1978 and 2012. Of these patients, 106 (37.2\%) were diagnosed with diabetes mellitus (DM). During the follow-up period, 21 cases of histological proved malignant in acromegalic patients, and DM with acromegaly had a higher incidence of malignancy $(13.2 \%$ vs. $3.8 \%$; $p<0.01)$. The $5-, 10-$, and 20 -year survival rates were $93.1 \%, 86.9 \%$, and $84.7 \%$ for the DM group, respectively, and $96.5 \%, 96.5 \%$, and $96.5 \%$ for the non-DM group, respectively. After a mean follow-up of $15.1 \pm 0.6$ years, age, DM, coronary heart disease, and malignancy were found to be significant factors of mortality. Control of growth hormone and IGF-1 levels also conferred a marginal survival benefit.

Conclusions: DM and malignancy significantly influence the survival of patients with acromegaly; thus, these patients need close follow-up and appropriate therapy. (Endokrynol Pol 2016; 67 (5): 501-506)
\end{abstract}

Key words: co-morbidities; malignancy; IGF-1

\section{Streszczenie}

Wstęp: W kilku badaniach klinicznych wykazano zwiększone ryzyko zgonu wśród pacjentów z niekontrolowaną akromegalią. Celem naszej pracy była ocena wpływu chorób towarzyszących na przeżycie pacjentów z akromegalią po długotrwałym leczeniu i czasie obserwacji. Materiał i metody: Retrospektywną analizę przeprowadzono w grupie 285 pacjentów z aktywną akromegalią, którzy byli przyjęci do Szpitala imienia Chang Gung w Tajwanie, w latach 1978-2012.

W powyższej grupie pacjentów, u $106(37,2 \%)$ rozpoznano cukrzycę (DM). W okresie obserwacji u pacjentów z akromegalią stwierdzono 21 potwierdzonych histopatologicznie przypadków nowotworów złośliwych ; częstość występowania nowotworów złośliwych była wyższa przy współwystępowaniu DM i akromegalii $(13,2 \%$ vs. 3,8\%; < 0.01). Odsetki 5-, 10- oraz 20-letnich przeżyć wyniosły odpowiednio: 93,1\%, 86,9\% i 84,7\% w grupie pacjentów z DM oraz 96,5\% ,96,5\% i 96,5\% w grupie chorych bez cukrzycy. Po średnim okresie obserwacji wynoszącym 15,1 \pm 0,6 lat: wiek, cukrzyca, choroba niedokrwienna serca oraz nowotwór złośliwy okazały się być czynnikami istotnie wpływającymi na śmiertelność. Wykazano także, że dobra kontrola stężenia hormonu wzrostu oraz IGF-1 miała granicznie korzystny wpływ na przeżycie.

Wnioski: Cukrzyca i nowotwór złośliwy istotnie wpływają na przeżycie pacjentów z akromegalią; dlatego też ta grupa pacjentów wymaga ścisłego monitorowania i odpowiednej terapii. (Endokrynol Pol 2016; 67 (5): 501-506)

Słowa kluczowe: choroby towarzyszące; nowotwór złośliwy; EGF-1

\section{Introduction}

Acromegaly is an unusual disease characterised by uncontrolled secretion of growth hormone $(\mathrm{GH})$ and insulin-like growth factor-1 (IGF-1). An increased risk of mortality in patients with uncontrolled acromegaly has been reported in several studies [1-3]. Compared with the general population, standardised mortality rates may be up to three-fold higher in patients with acromegaly [4]. However, their prognosis can be improved through adequate hormonal control using a combination of surgical therapy, medical therapy, and radiotherapy that have been developed over the past 20 years $[2,5,6]$. Cardiovascular and metabolic comorbidities remain important complications in patients with acromegaly $[7,8]$.

IGF-1 is an important cell growth-stimulating hormone. Different types of cancer have been shown to be associated with acromegaly $[9,10]$, and it has been speculated that the presence of hyperinsulinemia in 


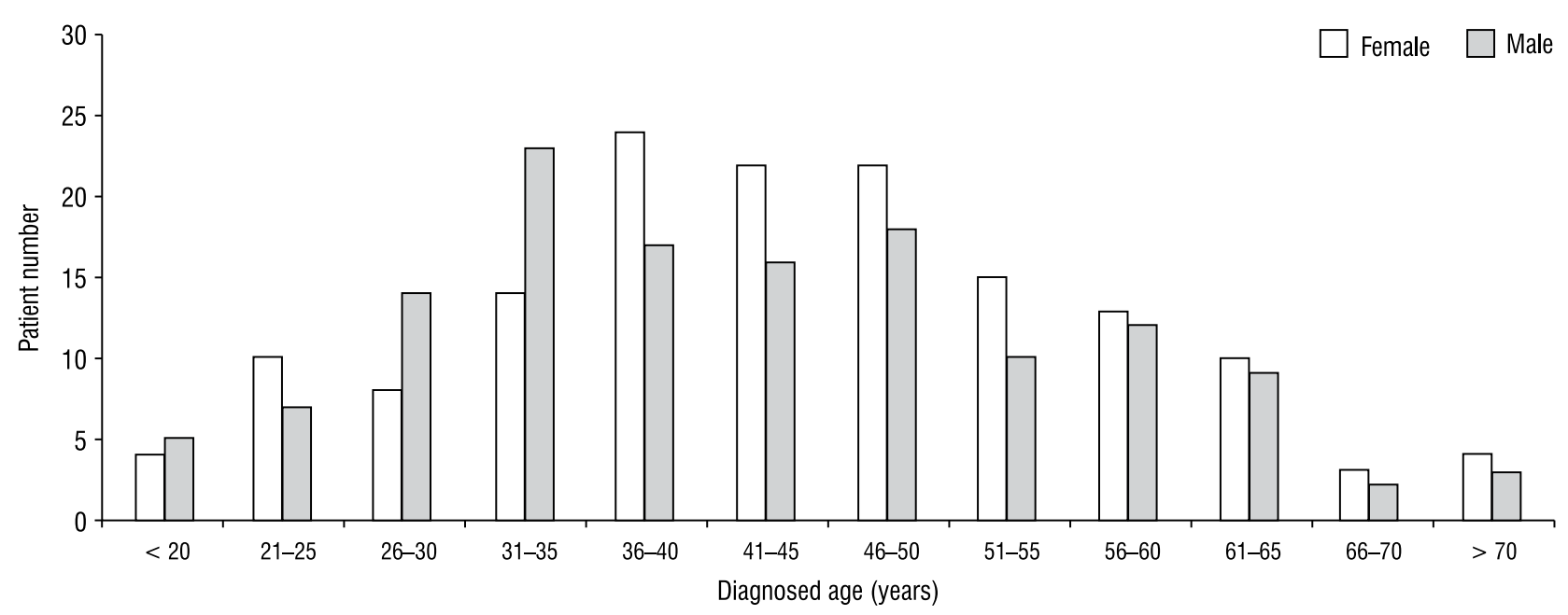

Figure 1. Age and gender distribution of 285 patients with acromegaly

Rycina 1. Rozkład wieku i ptci w grupie 285 pacjentów z akromegalia

patients with type 2 diabetes mellitus (DM) is one of the main factors causing malignancy $[11,12]$. This study aimed to analyse the long-term follow-up results of patients with acromegaly, who have undergone multimodal therapy. Furthermore, the presence of DM and cancer in these patients were compared in terms of data on different clinical laboratory markers.

\section{Material and methods}

A retrospective chart analysis was performed for 285 patients with active acromegaly (136 males and 149 females; mean age $\pm \mathrm{SE}, 43.4 \pm 0.8$ years; age range, 19-76 years; median age, 43.2 years), who were admitted to the Chang Gung Memorial Hospital in Linkou, Taiwan between 1978 and 2012. Figure 1 illustrates the age and gender distribution of the 285 patients. The highest proportions of female and male patients were in the age groups of 36-40 and 31-35 years, respectively. Clinical presentation, laboratory data, therapeutic modality, and follow-up outcome were coded for analysis. Of the 285 cases, 240 patients underwent surgical treatment. Most of these underwent transsphenoidal adenomectomy of the pituitary tumour. After 1994, stereotactic radiosurgery was performed for residual pituitary tumour with persistently high GH or IGF-1 levels after medical treatment [13].

Acromegaly was diagnosed on the basis of relevant clinical features, including a mean GH level $>5 \mathrm{ng} / \mathrm{mL}$, a plasma IGF-I level greater than the average age- and sex-matched levels, or a nadir GH after 75 gm oral glucose tolerance test (OGTT) $>1 \mathrm{ng} / \mathrm{mL}$. DM was defined as a fasting glucose level $>126 \mathrm{mg} / \mathrm{dL}$ or a postprandial glucose level $>200 \mathrm{mg} / \mathrm{dL}$ [14]. The diagnostic codes for malignancy were codes
140 to 208.91 of the ICD-9 clinical modification format. Coded data including clinical symptoms and signs, pre-operative and post-operative laboratory and imaging results, surgery results, complications, clinical outcomes of post-operative management, and mortality were analyzed. The study was approved by the Institutional Review Board of Chang Gung Memorial Hospital.

Chi-square and independent $t$-tests were used to assess differences in age, sex, and co-morbid conditions. One-way analysis of variance and Duncan post-hoc analysis were performed for cumulative survival with acromegaly (with or without) and DM (with or without) as within-subject factors. Logistic regression was used to estimate the odds ratio and 95\% confidence interval (CI) for associations between the acromegalic patients in mortality and survival groups. Kaplan-Meier survival curves were drawn for the various groups. In multivariate analysis, a stepwise technique was used to model survival. Statistical significance was set at $\mathrm{p}<0.05$. All analyses were conducted using the Statistical Package for Social Sciences Version 19 (SPSS Inc., Chicago, IL). Life tables for the general population were obtained from vital statistics published by the Department of Statistics, Ministry of the Interior, Executive Yuan, Taiwan [15].

\section{Results}

Of the 285 cases, the mean age of the 136 males (42.4 \pm 1.1 ; median, 41.7 years) was lower than that of the 149 females ( $44.2 \pm 1.1$; median, 43.6 years). Table I shows the clinical features and laboratory data of 285 acromegalic patients. Two hundred and forty patients 
Table I. Clinical features of 285 acromegalic patients

Tabela I. Charakterystyka kliniczna 285 pacjentów z akromegaliq

\begin{tabular}{ll}
\hline Parameter (Number) & Total (285) \\
\hline Mean age (Median) & $43.3 \pm 0.8(43.1)$ \\
\hline Female & $149(52.3 \%)$ \\
\hline GH (at diagnosis) & $42.9 \pm 3.2(26)$ \\
\hline GH (last data) & $8.5 \pm 2.1(1.9)$ \\
\hline IGF1 (at diagnosis) & $42.9 \pm 3.2(26)$ \\
\hline IGF1 (last data) & \\
\hline Clinical features & $265(93 \%)$ \\
\hline Increased acro-growth & $108(37.9 \%)$ \\
\hline Goitre & $102(35.8 \%)$ \\
\hline Headache & $100(35.1 \%)$ \\
\hline Osteoarthritis & $98(34.4 \%)$ \\
\hline Hypertension & $67(23.5 \%)$ \\
\hline Gonad dysfunction & $49(17.2 \%)$ \\
\hline - Amenorrhea & $18(6.3 \%)$ \\
\hline - Impotency & $67(23.5 \%)$ \\
\hline Visual impaired & $55(19.3 \%)$ \\
\hline Carpal tunnel syndrome & $12(4.2 \%)$ \\
\hline Galactorrhoea & $14(4.9 \%)$ \\
\hline Coronary artery disease & $45(15.8 \%)$ \\
\hline No surgical treatment & $162(57.7 \%)$ \\
\hline GH/IGF1 controlled & $21(7.4 \%)$ \\
\hline Sulignancy diagnosed & $74(26 \%)$ \\
\hline
\end{tabular}

underwent surgical treatment to remove the pituitary tumour. Forty-five patients received medical treatment or underwent observation (Fig. 2); these patients did not undergo surgical treatment due to underlying medical complications or patient refusal. After surgery, 66 patients underwent conventional radiotherapy or radiosurgery. Of the 285 patients, 106 patients (37.2\%) were diagnosed with DM. After age-matched with DM group (Table II), patients with DM had a higher incidence of diagnosed malignancy, goitre, and headache. DM had a lower survival rate than non-DM. In addition, a higher proportion of patients with DM did not undergo surgical treatment. Mean postoperative GH and IGF-1 levels were higher in the DM group than those in the non-DM group (GH: $14.6 \pm 3.3$ vs. $9.4 \pm$ $\pm 1.6 \mu \mathrm{g} / \mathrm{L}, \mathrm{p}=0.022 ; \mathrm{IGF}-1: 577.0 \pm 43.9 v s .470 .0 \pm 35.9 \mu \mathrm{g} / \mathrm{L}$ $\mathrm{p}=0.943)$; however, these differences were not sta-

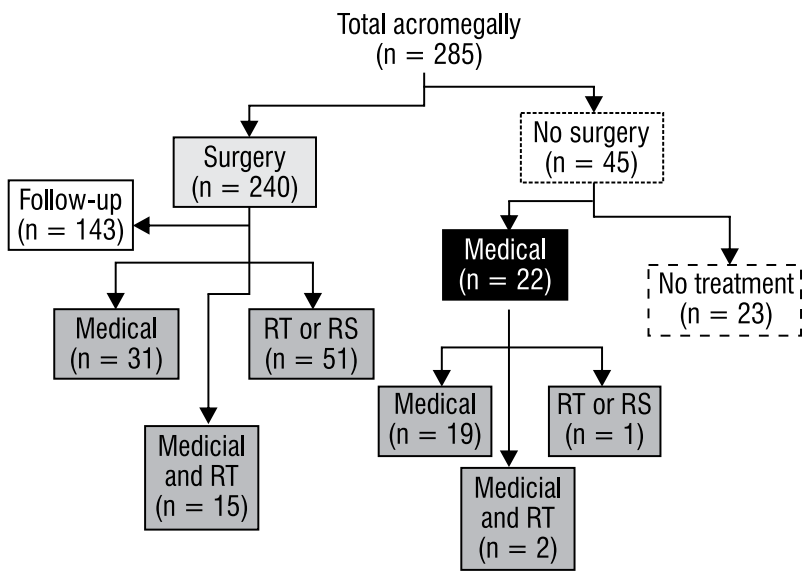

Figure 2. Flow-chart summarising total acromegaly cases and different therapeutic modalities of patients. (Medical: includes somatostatin analogues and dopamine agonist treatment; RT: conventional external radiotherapy; RS: radiosurgery)

Rycina 2. Diagram podsumowujący wszystkich pacjentów $z$ akromegalia oraz pacjentów leczonych różnymi metodami terapeutycznymi. (Substancje lecznicze: uwzględnia zastosowanie analogów somatostatyny oraz agonistów dopaminy; RT: konwencjonalna radioterapia z pól zewnętrznych; RS: radiochirurgia)

tistically significant. There were 98 patients (34.4\%) diagnosed with hypertension, and these patients were significantly older than patients without hypertension $(51.0 \pm 1.1$ vs. $45.0 \pm 0.8$ year; $p=0.18)$.

During the follow-up period, 21 patients $(7.4 \%)$ were diagnosed with cancer with different histological types. DM patients had a higher incidence of malignancy $(13.2 \%$ vs. $3.8 \%$; p < 0.01). Malignancy patients had a lower survival rate than non-malignancy patients $(61.1 \%$ vs. $94.1 \%$; $<<0.01)$. The survival rate of malignancy patients with DM was $50.0 \%$. Table III illustrates the anatomic site of malignancies in the 21 patients with acromegaly and cancer. Colon, thyroid, and head and neck cancers were the three leading cancer types. After a mean follow-up of $15.1 \pm 0.6$ years, there were 21 mortality cases. DM patients had a lower survival rate than non-DM patients $(86.8 \%$ vs. $96.2 \%$; $\mathrm{p}<0.01$ ). The five-, $10-$, and 20 -year survival rates were as follows: $93.1 \%, 86.9 \%$, and $84.7 \%$ for the DM group, respectively; $96.5 \%, 96.5 \%$, and $96.5 \%$ for the non-DM group, respectively; and $94.8 \%, 91.4 \%$, and $90.1 \%$ for all patients, respectively (Fig. 3). The cumulative survival rate of the general population was statistically higher than that of patients with acromegaly $(\mathrm{p}<0.05)$. In addition, non-DM patients with acromegaly had a higher cumulative survival rate than DM patients with acromegaly ( $\mathrm{p}<0.05)$.

Table IV displays the clinical features and laboratory data for patients in the mortality and survival groups until the end of 2012. Patients in the mortality 
Table II. Clinical features of acromegalic patients in DM and non-DM

Tabela II. Charakterystyka kliniczna pacjentów z akromegaliq z i bez towarzyszq̨cej cukrzycy

\begin{tabular}{|c|c|c|c|c|c|}
\hline Parameter (Number) & DM (106) & & Non-DM (106) & & Odds ratio $(95 \% \mathrm{CI})$ \\
\hline Mean age (Median) & $47.7 \pm 1.1(47.4)^{*}$ & & $47.3 \pm 0.9(45.8)$ & & $1.00(0.98,1.03)$ \\
\hline Female & 55 (51.9\%) & & $60(56.6 \%)$ & & $0.83(0.48,1.42)$ \\
\hline \multicolumn{6}{|l|}{ Clinical features } \\
\hline Increased acro-growth & 96 & $90.6 \%$ & 101 & $95.3 \%$ & $0.48(0.16,1.44)$ \\
\hline Goitre & 49 & $46.2 \% * *$ & 34 & $32.1 \%$ & $1.82(1.04,3.18)$ \\
\hline Headache & 42 & $39.6 \% * *$ & 27 & $25.5 \%$ & $1.92(1.07,3.45)$ \\
\hline Osteoarthritis & 35 & $33 \%$ & 41 & $38.7 \%$ & $0.78(0.45,1.37)$ \\
\hline Hypertension & 46 & $43.9 \%$ & 41 & $38.7 \%$ & $1.22(0.70,2.10)$ \\
\hline Gonad dysfunction & 28 & $26.4 \%$ & 33 & $31.1 \%$ & $0.79(0.44,1.44)$ \\
\hline — Amenorrhea & 22 & $20.8 \%$ & 26 & $24.5 \%$ & $0.81(0.42,1.54)$ \\
\hline - Impotency & 6 & $5.7 \%$ & 7 & $6.6 \%$ & $0.85(0.28,2.61)$ \\
\hline Visual impaired & 26 & $24.5 \%$ & 21 & $19.8 \%$ & $1.32(0.69,2.52)$ \\
\hline Carpal tunnel syndrome & 25 & $23.6 \%$ & 21 & $19.8 \%$ & $1.25(0.65,2.41)$ \\
\hline Galactorrhoea & 2 & $1.9 \%$ & 5 & $4.7 \%$ & $0.39(0.07,2.05)$ \\
\hline Coronary artery disease & 8 & $7.5 \%$ & 5 & $4.7 \%$ & $1.65(0.52,5.22)$ \\
\hline No surgical treatment & 23 & $21.7 \% *$ & 17 & $16.0 \%$ & $1.45(0.72,2.91)$ \\
\hline $\mathrm{GH} / \mathrm{IGF} 1$ controlled & 56 & $52.8 \%$ & 56 & $52.8 \%$ & $1.04(0.61,1.79)$ \\
\hline Malignancy diagnosed & 14 & $13.2 \%^{* *}$ & 4 & $3.8 \%$ & $3.88(1.23,12.21)$ \\
\hline Hypopituitarism & 23 & $27.1 \%$ & 22 & $20.8 \%$ & $0.94(0.48,1.88)$ \\
\hline Survival & 92 & $86.8 \% * *$ & 102 & $96.2 \%$ & $0.26(0.08,0.81)$ \\
\hline Follow-up period (years) & \multicolumn{2}{|l|}{$15.4 \pm 0.9(14.2)$} & \multicolumn{2}{|l|}{$13.5 \pm 0.7(12.8)$} & $1.03(0.99,1.07)$ \\
\hline
\end{tabular}

Mean $\pm \mathrm{SE}\left(\right.$ median); ${ }^{*} \mathrm{P}<0.05 ;{ }^{* *} \mathrm{P}<0.01$.

Table III. Anatomic patterns of malignancies in 21 acromegalic patients

Tabela III. Lokalizacja anatomiczna nowotworów złośliwych stwierdzonych u 21 pacjentów $z$ akromegaliq

\begin{tabular}{llll}
\hline Cancers & DM & Non-DM & Total \\
\hline Colon & 1 & 3 & 4 \\
\hline Thyroid & 3 & 1 & 4 \\
\hline Head and neck & 2 & 1 & 3 \\
\hline Breast (F) & 2 & 0 & 2 \\
\hline Skin & 1 & 1 & 2 \\
\hline Hepatoma & 1 & 0 & 1 \\
\hline Lung & 1 & 0 & 1 \\
\hline Haematological & 1 & 0 & 1 \\
\hline Gastric & 0 & 1 & 1 \\
\hline Cervical (F) & 1 & 0 & 1 \\
\hline CNS* & 1 & 0 & 1 \\
\hline Total & 14 & 7 & 21 \\
\hline
\end{tabular}

$\mathrm{CNS}^{*}$ — central nervous system

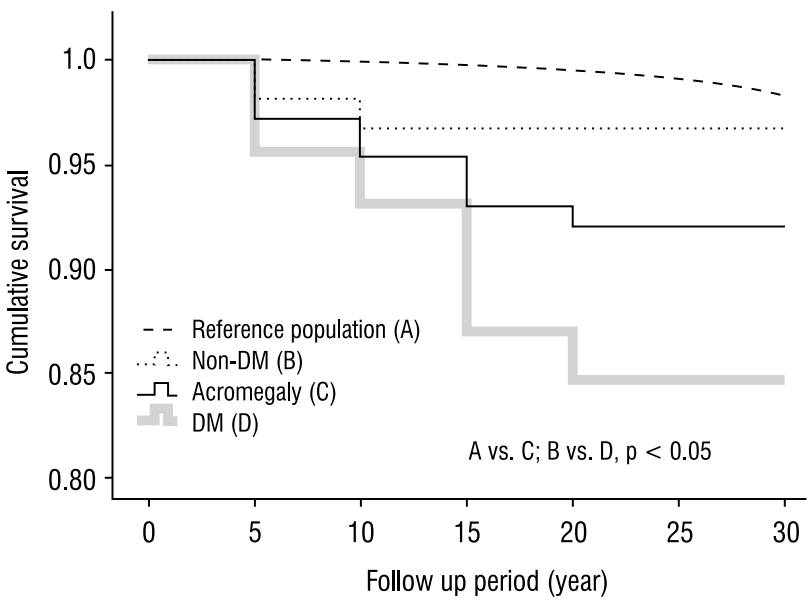

Figure 3. Cumulative survival curves for total acromegaly cases, acromegaly with or without diabetes mellitus, and a control group corresponding to the general population of Taiwan

Rycina 3. Skumulowane krzywe przeżycia dla wszystkich pacjentów z akromegaliq, dla pacjentów z akromegalia oraz bez towarzyszacej cukrzycy oraz dla grupy kontrolnej reprezentatywnej dla ogólnej populacji Tajwanu 
Table IV. Characteristics of acromegalic patients in mortality and survival groups Tabela IV. Charakterystyka kliniczna pacjentów z akromegaliq w obu grupach: zmarli oraz żyjący

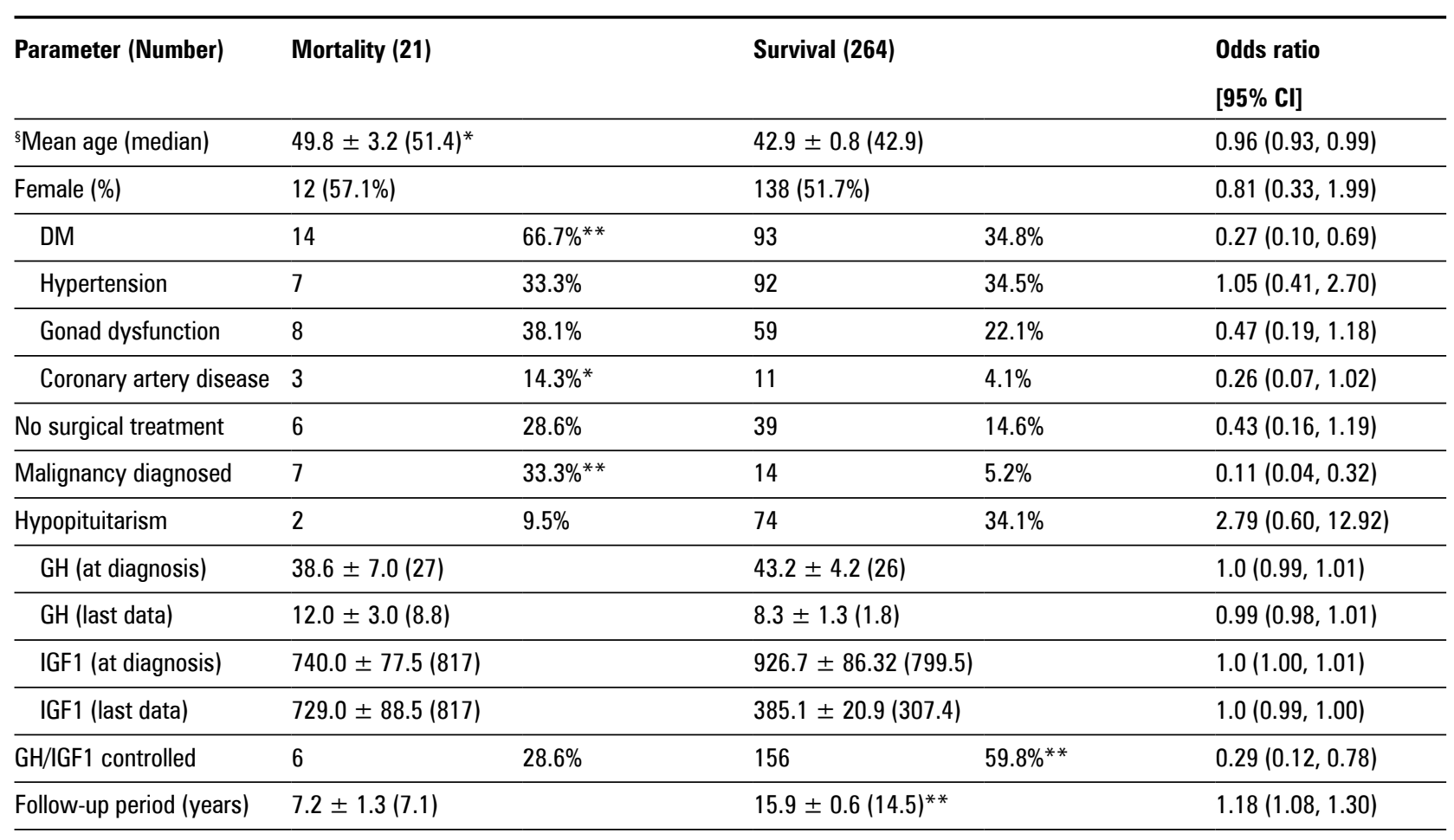

${ }^{\S}$ Mean age: mean $\pm \mathrm{SE}$ (median); ${ }^{*} \mathrm{P}<0.05 ;{ }^{* *} \mathrm{P}<0.01$.

group were significantly older than those in the survival group, but there were no significant differences in terms of gender. Patients diagnosed with DM, coronary heart disease, and malignancies had a significantly higher mortality rate. There were no statistically significant differences with respect to hypertension, gonad dysfunction, patients who did not undergo surgery, or hypopituitarism. In addition, neither GH nor IGF-1 levels were statistically different between diagnosis and final follow-up. However, for control patients, GH and IGF-1 levels were significantly higher in the survival group. Of the 21 mortality cases, eight were due to cancer, six were due to cardiovascular disease, three were due to infection, and one was due to suicide; the remaining three patients died of unknown causes.

\section{Discussion}

The mean age of our cohort was younger than that in most previous reports $[5,6,16,17]$. The disease activity of GH-producing tumours in patients with acromegaly has been suggested to be associated with visceral adiposity index and insulin sensitivity [18, 19]; however, IGF-I correlates more closely than GH with insulin resistance and glucose intolerance [20, 21]. Previous studies show that $16 \%$ to $52.5 \%$ of patients with acromegaly are diagnosed with DM [16, 22], with the inci- dence of DM varying depending on the prospective or retrospective nature of the study, different geographic area, nutritional habits, age, body mass index, and referral pattern [16]. Most studies have shown that among those with GH-producing tumours, survival rates of DM patients are lower than those of non-DM patients. Our results show that the DM group is older, but there were no gender differences. Data from an Italian group show that active acromegaly in women is strongly associated with higher visceral adiposity dysfunction, insulin resistance, and DM [22].

That elevated GH, IGF-1, and insulin levels in acromegaly are potentially involved in tumour promotion and progression has been a concern for several decades $[9,23]$. A variety of cancers, particularly colorectal, breast, and thyroid cancers, and perhaps haematological malignancies, were reported for a number of regions worldwide [24-26]. In our study, colon and thyroid cancers were the most frequently occurring malignancies with acromegaly; the results shown in this study, that the prevalence of colon and thyroid cancer is increased, are consistent with previous reports [24, 25]. A characteristic finding is that a higher percentage of patients with acromegaly and DM were diagnosed with malignancies than those without DM. As in our results, post-operative GH and IGF-1 levels were higher in the DM group. Although we did not check insulin levels, it is reasonable to believe that DM patients have 
higher insulin levels than non-DM patients $[9,21]$. The incidence of thyroid cancer in goitres associated with acromegaly is $3.67 \%$ (4 of 109 cases). This figure was not higher than that of a previous study by our group [27]. This previous study illustrated post-operatively that there were 858 cases of thyroid cancer in 21,748 patients with goitre. Thus, acromegalic patients with goitre should undergo periodic thyroid ultrasound examination.

Type 2 DM, obesity, and overweight have been associated with an increased risk of malignancy [28-30]. However, there is little information concerning the occurrence of malignancy in acromegaly patients with or without DM as in our study. Both DM and malignancy are important factors influencing the mortality of patients with acromegaly. Thus, the introduction of periodic cancer screening in acromegaly patients with DM is an important issue. The prevalence of hypertension varied remarkably between previous studies (18-60\%). In our study, hypertension was found to occur in $34.4 \%$ of patients, in comparison with $23.5 \%$ in the control population, which was matched for gender and age [31]. Differences in diagnostic criteria and in the techniques for measuring blood pressure may explain most of this variability. As for the general population, no gender differences were observed in our study, although prevalence increased with age. In addition, baseline and post-therapeutic GH and IGF-1 levels were not different between groups with or without hypertension. A limitation to our observational study is the fact that it took place during 30 years, and thus different assays were used for the measurement of GH and IGF-1 over this time; in addition, different surgeries and radiotherapies were carried out on patients.

In conclusion, acromegaly is not a rare disease, and multi-modal therapies are important methods for the management of this disease. However, metabolic disorders, such as DM, and malignancies can significantly influence patients' survival; thus, these patients require close follow-up and appropriate therapy.

\section{References}

1. Holdaway IM, Bolland MJ, Gamble GD. A meta-analysis of the effect of lowering serum levels of GH and IGF-I on mortality in acromegaly. Eur J Endocrinol 2008; 159: 89-95.

2. Dekkers OM, Biermasz NR, Pereira AM et al. Mortality in acromegaly: a metaanalysis. J Clin Endocrinol Metab 2008; 93: 61-67.

3. Biermasz NR, Dekker FW, Pereira AM et al. Determinants of survival in treated acromegaly in a single center: predictive value of serial insulinlike growth factor I measurements. J Clin Endocrinol Metab 2004; 89: 2789-2796.

4. Alexander L, Appleton D, Hall R et al. Epidemiology of acromegaly in the Newcastle region. Clin Endocrinol 1980; 12: 71-79.
5. Bogazzi F1, Colao A, Rossi G et al. Comparison of the effects of primary somatostatin analogue therapy and pituitary adenomectomy on survival in patients with acromegaly: a retrospective cohort study. Eur J Endocrinol 2013; 169: 367-376.

6. Fukuda I, Hizuka N, Muraoka T et al. Clinical features and therapeutic outcomes of acromegaly during the recent 10 years in a single institution in Japan. Pituitary 2014; 17: 90-95.

7. Annamalai AK, Webb A, Kandasamy N et al. A comprehensive study of clinical, biochemical, radiological, vascular, cardiac, and sleep parameters in an unselected cohort of patients with acromegaly undergoing presurgical somatostatin receptor ligand therapy. J Clin Endocrinol Metab 2013; 98: 1040-1050.

8. Espinosa-de-los-Monteros AL, González B, Vargas G et al. Clinical and biochemical characteristics of acromegalic patients with different abnormalities in glucose metabolism. Pituitary 2011; 14: 231-235.

9. Clayton PE, Banerjee I, Murray PG et al. Growth hormone, the insulinlike growth factor axis, insulin and cancer risk. Nat Rev Endocrinol 2011; 7: 11-24.

10. Wolinski K, Czarnywojtek A, Ruchala M. Risk of thyroid nodular disease and thyroid cancer in patients with acromegaly--meta-analysis and systematic review. PLoS One 2014; 9: e88787.

11. Khandwala HM, McCutcheon IE, Flyvbjerg A et al. The effects of insulin-like growth factors on tumorigenesis and neoplastic growth. Endocr Rev 2000; 21: 215-244.

12. Bensimon L, Yin H, Suissa S et al. Type 2 diabetes and the risk of mortality among patients with prostate cancer. Cancer Causes Control 2014; 25: 329-338.

13. Yan JL, Chang CN, Chuang CC et al. Long-term follow-up of patients with surgical intractable acromegaly after linear accelerator radiosurgery. J Formos Med Assoc 2013; 112: 416-420.

14. American Diabetes Association. Diagnosis and classification of diabetes mellitus. Diabetes Care 2010; 33 (supl. 1): S62-69.

15. Fang CT, Chang YY, Hsu HM et al. Life expectancy of patients with newly-diagnosed HIV infection in the era of highly active antiretroviral therapy. QJM 2007; 100: 97-105.

16. Arosio M, Reimondo G, Malchiodi E, Berchialla P et al; Italian Study Group of Acromegaly. Predictors of morbidity and mortality in acromegaly: an Italian survey. Eur J Endocrinol 2012; 167: 189-198.

17. Broder MS, Neary MP, Chang E et al. Treatments, complications, and healthcare utilization associated with acromegaly: a study in two large United States databases. Pituitary 2014; 17: 333-341.

18. Mori K, Iwasaki Y, Kawasaki-Ogita Y et al. Improvement of insulin resistance following transsphenoidal surgery in patients with acromegaly: correlation with serum IGF-I levels. J Endocrinol Invest 2013; 36: 853-859.

19. Alexopoulou O, Bex M, Kamenicky P et al. Prevalence and risk factors of impaired glucose tolerance and diabetes mellitus at diagnosis of acromegaly: a study in 148 patients. Pituitary 2014; 17: 81-89.

20. Ciresi A, Amato MC, Pivonello R et al. The metabolic profile in active acromegaly is gender-specific. J Clin Endocrinol Metab 2013; 98: E51-59.

21. Niculescu D, Purice M, Coculescu M. Insulin-like growth factor-I correlates more closely than growth hormone with insulin resistance and glucose intolerance in patients with acromegaly. Pituitary 2013; 16: 168-174.

22. Dreval AV, Trigolosova IV, Misnikova IV et al. Prevalence of diabetes mellitus in patients with acromegaly. Endocr Connect 2014; 3: 93-98.

23. Jenkins P. Cancer in acromegaly. Trends Endocrinol Metab 1998; 9: 360-366.

24. Wolinski K, Czarnywojtek A, Ruchala M. Risk of thyroid nodular disease and thyroid cancer in patients with acromegaly - meta-analysis and systematic review. PLoS One 2014; 9: e88787.

25. Rokkas T, Pistiolas D, Sechopoulos P et al. Risk of colorectal neoplasm in patients with acromegaly: a meta-analysis. World J Gastroenterol 2008; 14: 3484-3489.

26. Jenkins PJ. Cancers associated with acromegaly. Neuroendocrinology 2006; 83: 218-223.

27. Lin JD, Chao TC, Huang BY et al. Thyroid cancer in the thyroid nodules evaluated by ultrasonography and fine needle aspiration cytology. Thyroid 2005; 15: 708-717.

28. Atchison EA, Gridley G, Carreon JD et al. Risk of cancer in a large cohort of U.S. veterans with diabetes. Int J Cancer 2011; 128: 635-643.

29. Johnson JA, Pollak M. Insulin, glucose and the increased risk of cancer in patients with type 2 diabetes. Diabetologia 2010; 53: 2086-2088.

30. Bianchini F, Kaaks R, Vainio H. Overweight, obesity, and cancer risk. Lancet Oncol 2002; 3: 565-574.

31. Sua TC, Baib CH, Chang HY et al. Evidence for improved control of hypertension in Taiwan: 1993-2002. J Hypertens 2008; 26: 600-606. 